\title{
Chromium uptake and loss in the bivalves Crassostrea virginica and Mytilus edulis*
}

\author{
G. E. Zaroogian and M. Johnson \\ Environmental Research Laboratory, US Environmental Protection Agency, South Ferry Road, Narragansett, \\ Rhode Island 02882, USA
}

\begin{abstract}
Chromium uptake and loss by the bivalves Crassostrea virginica and Mytilus edulis were studied at naturally occurring seawater temperature and salinity to determine their potential as an indicator of chromium pollution. After $12 \mathrm{wk}$ treatment with 5 and $10 \mathrm{ppb} \mathrm{Cr}$ seawater, mean tissue concentration in oysters, C. virginica, was $3.12 \pm .45$ and $5.63 \pm 1.15 \mu \mathrm{g} \mathrm{Cr} \mathrm{g}^{-1}$ dry weight, respectively. Mean chromium concentration in mussels, $M$. edulis, treated with 5 and $10 \mathrm{ppb} \mathrm{Cr}$ seawater for 12 wk were $4.83 \pm 1.32$ and $9.41 \pm 3.37 \mu \mathrm{g} \mathrm{Cr} \mathrm{g}^{-1}$ dry weight, respectively. Significant linear relationships exist between chromium uptake by oysters and mussels and seawater chromium concentrations over the range of concentrations used in this study. A significant inverse relationship exists between tissue chromium concentration and dry weight in both oysters and mussels. Chromium concentration in oysters continued to increase during spawning, whereas it decreased in mussels. After holding chromium treated mussels in ambient flowing seawater for $28 \mathrm{wk}$, a 61 and $70 \%$ loss of chromium occurred in mussels treated with 5 and $10 \mathrm{ppb} \mathrm{Cr}$, respectively. When treated similarly, oysters from both the 5 and $10 \mathrm{ppb} \mathrm{Cr}$ treatments lost $42 \%$ of their tissue chromium after 28 wk depuration. Evidence is presented which suggests that oysters would be a better indicator of chromium pollution of the environment than mussels.
\end{abstract}

\section{INTRODUCTION}

Chromium has long been an item of commerce and has great economic importance. Despite its long history, many aspects of the element, particularly its interaction with the environment, remain obscure.

Compared to trivalent chromium compounds, hexavalent chromium compounds have the greater economic importance as well as the greater biological and environmental significance (Towill et al., 1978). Sodium dichromate is the leading commercial form of chromium and almost all other chromium compounds are prepared from it. Therefore, this chromium compound more than any other is probably more likely to enter estuaries.

Ambient chromium concentrations in seawater are low, with a range of 0.25 to $0.5 \mu \mathrm{g} \mathrm{l}^{-1}$ (Bond et al., 1973). Hexavalent chromium rarely occurs naturally because it is readily reduced in the presence of organic matter. However, after introduction by man, hexava-

- Contribution No. 338, Environmental Research Laboratory, US Environmental Protection Agency, South Ferry Road, Narragansett, R. I., 02882 USA lent chromium often remains unchanged in many natural waters because of low concentrations of reducing matter (Mertz et al., 1974). Chromium in seawater can be either tri- or hexavalent; however, Fukai (1967) suggested that the stable chromium species in seawater was hexavalent.

Chromium is released into the environment from many sources, and small amounts are taken up by a wide variety of organisms (Towill et al., 1978). Although environmental interactions of chromium have not been studied adequately, chromium does not appear to be biomagnified in aquatic food chains despite its accumulation by certain organisms (Baptist and Lewis, 1969; Mathis and Cummings, 1973). Chromium uptake by oysters has been reported by Pringle et al. (1968) and Shuster and Pringle (1969). However, they treated oysters with trivalent chromium under laboratory conditions and with chromium concentrations ( 0.05 to $0.1 \mathrm{mg} \mathrm{l}^{-1}$ ) that far exceeded those expected in the environment.

Since little is known about the impact of low chromium concentrations on oysters and mussels, we initiated studies in which Crassostrea virginica and Mytilus edulis were treated with 2 concentrations of 
hexavalent chromium under otherwise ambient seawater conditions. Our study focused on the kinetics of bioaccumulation and depuration of hexavalent chromium by oysters and mussels over an extended period of time and to determine if either species would be a good biological indicator of chromium in nearshore marine waters.

\section{MATERIALS AND METHODS}

Test organisms were adult oysters Crassostrea virginica Gmelin obtained from Cotuit Sound, Massachusetts, USA, and adult mussels Mytilus edulis Linnaeus obtained from Narragansett Bay, Rhode Island, USA, in May 1979. The mean height of the oysters was $9.5 \pm 0.3 \mathrm{~cm}$ and that of the mussels was $6.7 \pm 1.5 \mathrm{~cm}$. Histopathologic examination, which was used to determine the general health condition of oysters and mussels at the time of harvest and at the start of chromium addition to the experimental troughs, did not show any abnormalities. Oysters and mussels were acclimatized for 1 mo in fiberglass troughs with a flowthrough seawater system using unfiltered Narragansett Bay water. The troughs measured $3.75 \mathrm{~m}$ long $\times 30 \mathrm{~cm}$ wide $\times 25 \mathrm{~cm}$ deep and were supplied with flowing unfiltered seawater ( 29 to $32 \%$ S) at the rate of $20 \mathrm{lmin}^{-1}$. Each trough held either 50 oysters or 50 mussels on a false bottom consisting of polyethylene grids resting $2.5 \mathrm{~cm}$ off the trough bottom on PVC pipe. The oysters and mussels did not receive supplementary feeding during the holding or treatment periods. The ambient seawater temperature was continuously recorded during the experiment.

Six troughs holding oysters ( 3 per chromium treatment) received a sodium dichromate solution $\left(\mathrm{Na}_{2} \mathrm{Cr}_{2} \mathrm{O}_{7} \cdot 2 \mathrm{H}_{2} \mathrm{O}\right.$ ) and 3 troughs served as controls. A duplicate system for mussels was used. A deionized water stock-solution was pumped into the troughs at a rate, which when mixed with incoming seawater (20 1 min $^{-1}$ ), produced a calculated concentration of 5.0 or $10.0 \mathrm{ppb} \mathrm{Cr}$.

Five oysters and mussels were removed from each treatment and the tissue chromium concentration determined prior to dosing with chromium in June (Time 0). During the accumulation period (June to August), 5 oysters and 5 mussels were removed from each treatment biweekly for $12 \mathrm{wk}$ and analyzed for chromium. The first sample in the depuration study was taken after $14 \mathrm{wk}$ ( $2 \mathrm{wk}$ after termination of dosing) and biweekly thereafter to Week 20.

Chromium concentrations in the experimental troughs were determined by heated graphite atomization (HGA) using a Perkin-Elmer Model HGA 2100 coupled with a Perkin-Elmer Model 360 atomic absorption (AA) spectrophotometer. Prior to analysis,
$100 \mu \mathrm{l}$ of concentrated $\mathrm{HNO}_{3}$ (ultra-pure grade) were added to $1 \mathrm{ml}$ of each of the test samples. Standards for the chromium determinations were prepared in ambient seawater to match salinities of the test solutions in order to provide matrix matching and eliminate differences between standards and test samples. Replicate seawater samples were determined for each chromium concentration. Each sample and standard were injected twice into the HGA unit and the average concentration with its standard deviation was determined. The detection limit for chromium with this technique is approximately $1 \mu \mathrm{g} \mathrm{kg}^{-1}$ of seawater. Seawater in the control troughs contained a mean concentration less than $1 \mathrm{ppb}$ (i.e. detection limit). The mean concentrations in the troughs holding oysters were $5.13 \pm .43$ (range 4.20 to 5.81 ) and $10.60 \pm .66$ (range 8.83 to 11.62 ) for the 5 and $10 \mathrm{ppb} \mathrm{Cr}$ treatments, respectively. Those troughs holding mussels had mean concentrations of $5.05 \pm .35$ (range 4.06 to 5.91) and $10.06 \pm .53$ (range 8.70 to 11.61 ) for the 5 and $10 \mathrm{ppb} \mathrm{Cr}$ treatments, respectively. No chemical separation or matrix modification techniques were used to enhance the detection limit for chromium.

The total soft parts of oysters and mussels to be analyzed by atomic absorption spectrophotometry were removed from the shells and oven-dried at $100^{\circ} \mathrm{C}$ prior to wet ashing in concentrated $\mathrm{HNO}_{3}$ (reagent grade). Tissue samples were digested in concentrated $\mathrm{HNO}_{3}$ at $80^{\circ} \mathrm{C}$ for several days. All soluble organic compounds were decomposed with careful addition of $30 \% \mathrm{H}_{2} \mathrm{O}_{2}$ to the $\mathrm{HNO}_{3}$ solutions after the initial digestion period. The clear solution obtained with repeated addition of $\mathrm{H}_{2} \mathrm{O}_{2}$ was concentrated to approximately $2 \mathrm{ml}$ and reconstituted with $5 \% \mathrm{HNO}_{3}$. The solution was filtered through Whatman \# 42 filters (previously washed with $5 \% \mathrm{HNO}_{3}$ ) and brought to final volume (50 ml) with $5 \% \mathrm{HNO}_{3}$. Blanks were processed concurrently with each set of 15 tissue samples. The blank samples were subjected to the same rigorous treatment as the tissue samples (i.e. $\mathrm{HNO}_{3}, \mathrm{H}_{2} \mathrm{O}_{2}$ and filtration).

Calibration of the AA spectrophotometer was performed before and after the analysis of 30 samples and recalibration checks were performed after every 5 samples. Each sample and standard were injected at least 3 times into the HGA unit to determine the reproducibility of the measured signal and the mean of the 3 determinations was used to compute the concentrations for each sample. A minimum of $10 \%$ of all samples was determined by standard addition. Matrix effects were found to be non-existent in the tissue samples since differences greater than $10 \%$ were not obtained for any of the samples analyzed by the standard comparison method. Blank samples were generally undetectable and contributed less than $10 \%$ to the lowest value reported. 
Regression analyses were performed to determine the influence of seawater chromium concentration, time and weight on uptake and depuration of chromium by oysters and mussels.

\section{RESULTS}

The mean concentration of chromium in oysters and mussels was significantly $(\mathrm{P}<0.05)$ different between treatments. As much as $3.12 \pm .45$ and $5.63 \pm 1.15 \mu \mathrm{g}$ $\mathrm{Cr} \mathrm{g}^{-1}$ dry weight were accumulated by adult oysters from seawater containing 5 and $10 \mathrm{ppb} \mathrm{Cr}$, respectively, after $12 \mathrm{wk}$ treatment (Fig. 1). Adult mussels
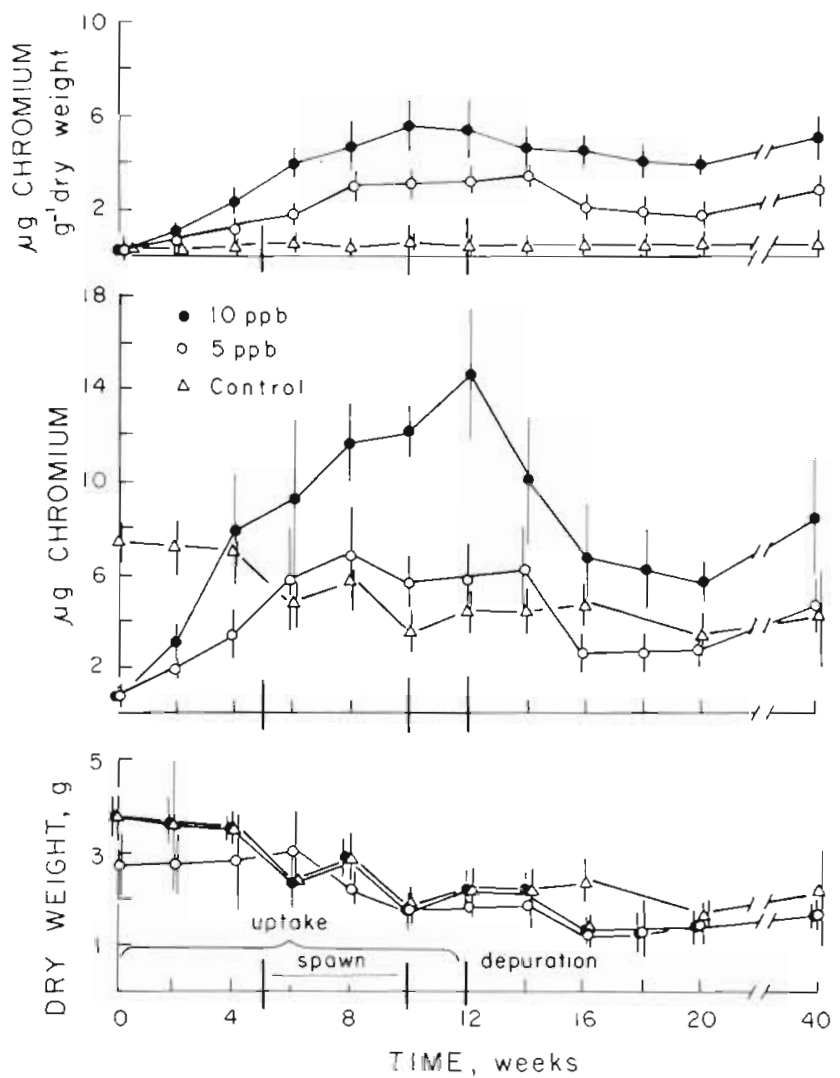

Fig. 1. Crassostrea virginica. Dry weight, chromium content and chromium concentration in the total soft parts of oysters treated with ambient (control) 5 and 10 ppb chromium seawater for 12 wk (June to August, 1979). Each symbol represents the mean value from each sample of 5 oysters \pm 1 standard deviation

contained $4.83 \pm 1.32$ and $9.41 \pm 3.37 \vartheta \mathrm{g} \mathrm{Cr} \mathrm{g}{ }^{-1} \mathrm{dry}$ weight after $12 \mathrm{wk}$ treatment with seawater containing 5 and $10 \mathrm{ppb} \mathrm{Cr}$, respectively (Fig. 2).

Linear regression analyses showed that slopes for time of treatment increased significantly $(\mathrm{P}<0.05)$ for oysters but not for mussels as the chromium concentration increased in the troughs. In the $5 \mathrm{ppb} \mathrm{Cr}$ treatment, tissue chromium concentration increased sig- nificantly $(P<0.01)$ at the same rate in oysters and mussels. However, the rate of increase of tissue chromium concentration in mussels treated with $10 \mathrm{ppb} \mathrm{Cr}$ was not significantly $(\mathrm{P}>0.05)$ different from that obtained with the $5 \mathrm{ppb} \mathrm{Cr}$ treatment. In contrast, the rate of tissue concentration increase in oysters $(\mathrm{P}<0.01)$ treated with $10 \mathrm{ppb} \mathrm{Cr}$ seawater was almost double that obtained with the $5 \mathrm{ppb} C \mathrm{Cr}$ treatment.

The coefficient of determination $\left(R^{2}\right)$ for the significant $(P<0.05)$ linear models of chromium uptake by the oysters is 0.87 for both the 5 and $10 \mathrm{ppb} \mathrm{Cr}$ treatments. In contrast, the $\mathrm{R}^{2}$ values for the significant $(\mathrm{P}<0.05)$ linear models of chromium uptake by mussels are 0.71 and 0.50 for the 5 and $10 \mathrm{ppb} \mathrm{Cr}$ treatments, respectively. Therefore, it appears that chromium uptake by the oyster is better fit by a linear model than that of the mussel.

Uptake pattems expressed as chromium concentration ( $\mu \mathrm{g} \mathrm{g}^{-1}$ ) suggested that chromium increased continuously in oyster tissues over the $12 \mathrm{wk}$ uptake period (Fig. 1). Oysters continued to accumulate chromium during their natural spawning period which was observed in the experimental troughs and confirmed by histopathological examination during Weeks 5 to 10 (Fig. 1). Uptake, expressed as content $(\mu \mathrm{g})$ decreased during Week 10 which coincided with spawning in the $5 \mathrm{ppb}$ Cr treatment. However, uptake as content continued to increase in the oysters through the spawning period in the $10 \mathrm{ppb} \mathrm{Cr}$ treatment (Fig. 1).

In contrast, chromium uptake, as concentration in mussels, decreased during their natural spawning period, which was observed in the experimental troughs and confirmed by histopathological examination during Weeks 5 to 10 (Fig. 2). Although a decrease in chromium content and dry weight did occur during spawning in the control mussels and those treated with $5 \mathrm{ppb} \mathrm{Cr}$, these decreases were not as apparent as those observed in the $10 \mathrm{ppb} \mathrm{Cr}$ treatment (Fig. 2).

A significant $(P<0.05)$ inverse relationship was observed between chromium concentration in the soft tissues and dry weight; whereas, a significant $(P<0.05)$ direct relationship existed between chromium content and dry weight in both oysters and mussels. Linear regression analyses indicated that in the control, 5 and $10 \mathrm{ppb}$ Cr treatments there was no significant $(P>0.05)$ change in dry weight of mussels during the uptake period (Weeks 0 to 12; Fig. 2). In addition, no significant $(\mathrm{P}>0.05)$ change in dry weight of mussels from all treatments occurred during the spawning period (Weeks 5 to 10). Although it appeared that oysters were losing weight during the uptake period, linear regression analyses indicated that no significant $(\mathrm{P}>0.05)$ change in dry weight of oysters 

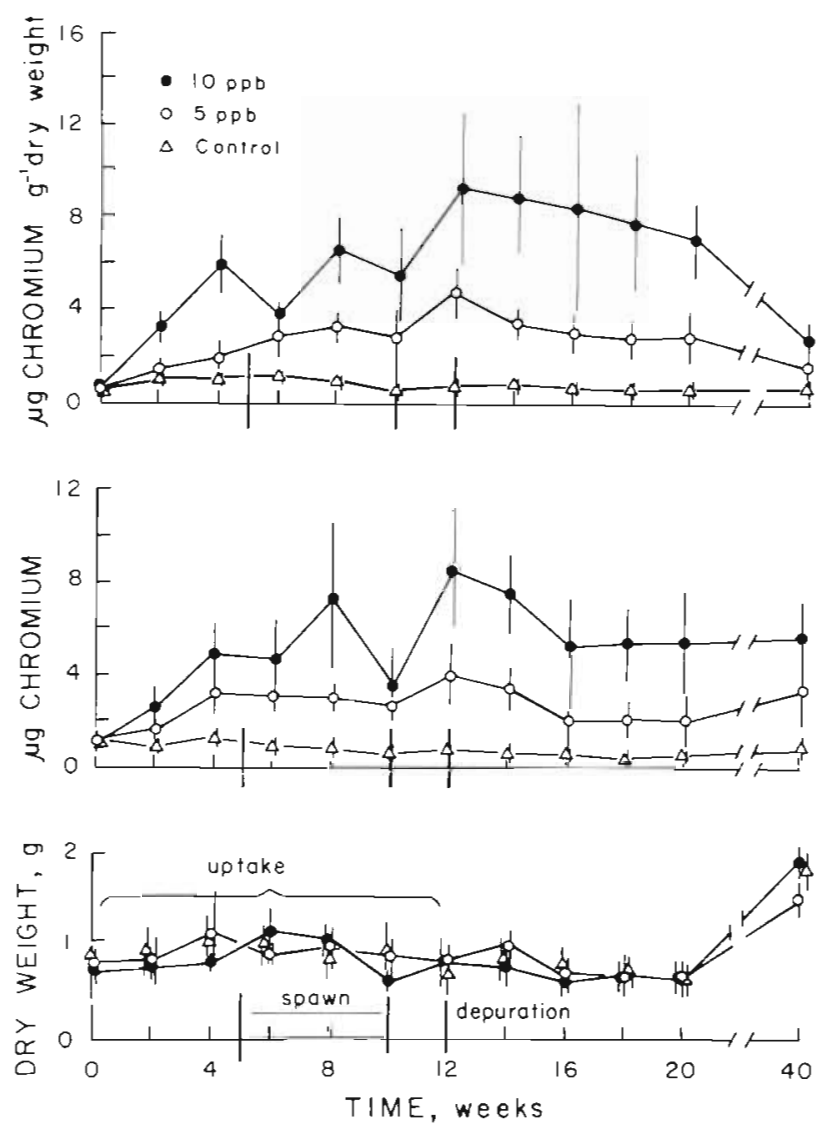

Fig. 2. Mytilus edulis. Dry weight, chromium content and chromium concentration in the total soft parts of oysters treated with ambient (control), 5 and $10 \mathrm{ppb}$ chromium seawater for 12 wk (June to August, 1979). Each symbol represents the mean value from each sample of 5 oysters \pm 1 standard deviation

from the control and $5 \mathrm{ppb} \mathrm{Cr}$ treatments occurred during chromium uptake (Weeks 0 to 12) (Fig. 1). However, linear regression analyses indicated that a significant $\left(P<0.01, R^{2}=0.56\right)$ loss in dry wt occurred during the uptake period (Weeks 0 to 12) in oysters treated with $10 \mathrm{ppb} \mathrm{Cr}$ (Fig. 1). In addition, linear regression analyses suggested that dry weight loss in oysters during spawning (Weeks 5 to 10) was significant $(P<0.05)$ in the control, 5 and $10 \mathrm{ppb} C r$ treatments.

Chromium concentration and content in mussels treated with $10 \mathrm{ppb}$ Cr continued to decrease throughout the $8 \mathrm{wk}$ depuration period (Weeks 12 to 20; Fig. 2), Chromium concentration in mussels treated with $5 \mathrm{ppb} \mathrm{Cr}$ did not continue to decrease after $6 \mathrm{wk}$ depuration (Week 18; Fig. 2). After treatment with $5 \mathrm{ppb} \mathrm{Cr}$ for $12 \mathrm{wk}$, mussels lost $28 \%$ of their tissue chromium concentration within the first 2 wk after chromium addition to the troughs was discontinued (Fig. 2). An additional $21 \%$ chromium was lost during the following $4 \mathrm{wk}$ depuration (Weeks 14 to 18) for a total chromium loss of $49 \%$ over the $6 \mathrm{wk}$ period (Fig. 2). In mussels treated with $10 \mathrm{ppb} \mathrm{Cr}_{1}$ a $9 \%$ loss in chromium concentration was observed $4 \mathrm{wk}$ after chromium addition to the troughs was terminated; whereas, during the next $4 \mathrm{wk}, 25 \%$ of the chromium was lost to give a total chromium loss of $34 \%$ over the 8 wk depuration period (Fig. 2).

In an attempt to determine the maximum loss of chromium from mussels, those mussels which remained after $20 \mathrm{wk}$ of study were allowed to depurate in ambient flowing seawater $\left(20 \mathrm{I} \mathrm{min}^{-1}\right)$ for an additional $20 \mathrm{wk}$. Thus, $28 \mathrm{wk}$ after chromium addition to the troughs was terminated, a 61 and $70 \%$ loss of chromium occurred in mussels treated with 5 and $10 \mathrm{ppb} \mathrm{Cr}$, respectively.

Although body burdens were higher in mussels treated with $10 \mathrm{ppb} \mathrm{Cr}$ than in those treated with $5 \mathrm{ppb}$ $\mathrm{Cr}$, analyses of covariance (Snedecor and Cochran, 1967) which were used to test slope equality indicated that when chromium loss occurred (Weeks 12 to 20) the rates of loss were not significantly $(\mathrm{P}>0.05)$ different between treatments. Although the rate of chromium loss in mussels is the same between treatments, the amount of chromium loss differs significantly $(\mathrm{P}<0.05)$. Thus the same percentage chromium loss occurs in mussels from both treatments but the body burdens remain higher in the mussels treated with $10 \mathrm{ppb} \mathrm{Cr}$ than in those treated with $5 \mathrm{ppb} \mathrm{Cr}$.

Tests for slope equality (analyses of covariance) indicated that significant differences do not exist $(P>0.05)$ between rate of chromium loss as concentration and content in mussels treated with $5 \mathrm{ppb} \mathrm{Cr}$. These same analyses suggested that in mussels treated with $10 \mathrm{ppb}$ $\mathrm{Cr}$, the rate of chromium loss as content was significantly $(P<0.05)$ greater than chromium loss as concentration (slopes of regression lines for chromium loss as content and concentration are -0.36 and -0.28 , respectively). Weight fluctuations do not appear to be responsible for the differences in rates of chromium loss since weight remained stable during the depuration period (Weeks 12 to 20; Fig. 2).

During the first $4 \mathrm{wk}$ of depuration when seawater temperatures were in excess of $20^{\circ} \mathrm{C}$, the chromium concentration decreased by 43 and $9 \%$ in mussels treated with 5 and 10 ppb Cr, respectively (Figs. 2 and 3). During the following $24 \mathrm{wk}$, seawater temperatures decreased continuously, and tissue chromium concentration decreased an additional 18 and $41 \%$ in mussels treated with 5 and $10 \mathrm{ppb} \mathrm{Cr}$, respectively (Figs. 2 and 3). Chromium concentration in oysters treated with $5 \mathrm{ppb} \mathrm{Cr}$ did not decrease during the first $2 \mathrm{wk}$ of depuration (14 wk); however, after $4 \mathrm{wk}$ depuration, chromium concentration decreased by $36 \%$ (Fig. 1). Oysters treated with $10 \mathrm{ppb} \mathrm{Cr}$, unlike those treated with $5 \mathrm{ppb} \mathrm{Cr}$, lost chromium during the first $2 \mathrm{wk}$ 
depuration and lost $18 \%$ chromium after 4 wk depuration (Fig. 1). A $50 \%$ loss of chromium from oysters treated with 5 or $10 \mathrm{ppb}$ Cr was not observed up to 8 wk depuration.

In an attempt to determine the maximum loss of chromium from oysters, those oysters which remained after $20 \mathrm{wk}$ of study were allowed to depurate in ambient flowing seawater $\left(20 \mathrm{l} \mathrm{min}^{-1}\right)$ for an additional 20 wk. After 28 wk depuration, a $42 \%$ decrease in chromium concentration occurred in oysters from both the 5 and $10 \mathrm{ppb}$ Cr treatments.

Although chromium body burdens were higher in oysters treated with $10 \mathrm{ppb}$ Cr than in those treated with $5 \mathrm{ppb} \mathrm{Cr}$, tests for slope equality (analyses of covariance) indicated that the rates of chromium loss were not significantly different $(\mathrm{P}>0.05)$ between treatments. Although the rate of chromium loss in oysters is the same between treatments, analyses of covariance suggested that the amount of chromium lost differs significantly $(\mathrm{P}<0.05)$ between treatments. Thus, the same percentage chromium loss occurs in oysters from both treatments, but body burdens remain higher in oysters treated with $10 \mathrm{ppb} \mathrm{Cr}$ than in those treated with $5 \mathrm{ppb} \mathrm{Cr}_{\mathrm{r}}$ after $28 \mathrm{wk}$ depuration. The rate of chromium loss as content is significantly greater $(P<0.05)$ than chromium loss as concentration in oysters from both the 5 and $10 \mathrm{ppb}$ Cr treatments.

During the first $4 \mathrm{wk}$ of depuration (Weeks 12 to 16) when seawater temperatures were in excess of $20^{\circ} \mathrm{C}$, the chromium concentration in oyster tissue decreased 38 and $18 \%$ in the 5 and 10 ppb Cr treatments, respectively (Figs. 1 and 3). Seawater temperature decreased continuously for the following 24 wk depuration; and at the end of this period, chromium concentration in oysters treated with 5 and $10 \mathrm{ppb} \mathrm{Cr}$ decreased an additional 6 and $24 \%$, respectively.

\section{DISCUSSION}

Though our results indicate that chromium uptake in Crassostrea virginica and Mytilus edulis is linear, Shuster and Pringle (1969) reported that chromium accumulation by $C$. virginica was curvilinear and occurred in 3 phases when temperature was maintained at $20^{\circ} \mathrm{C}$ for $20 \mathrm{wk}$. The logarithmic plots of our oyster and mussel uptake data were similar to that reported by Shuster and Pringle (1969); however, 3 phases of uptake were not apparent in our plots.

Ayling (1974) suggested that oysters absorb chromium by a physiological process up to a maximum concentration that depended upon the size of the oyster. In addition, Ayling (1974) reported that chromium concentration in Crassostrea gigas is not related to size; whereas, the total content is directly related to

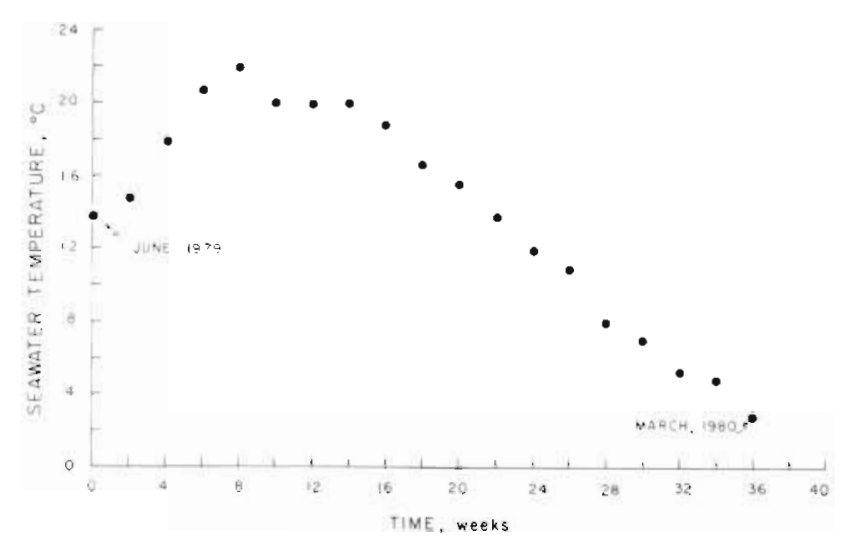

Fig. 3 Crassostrea virginica. Weekly mean seawater temperature during chromium treatment and depuration

size. In this study, tissue chromium concentration is inversely related with weight and tissue chromium content directly related with weight. This is not unique to this study since similar findings have been reported (Cunningham and Tripp, 1975; Mackay et al., 1975; Watling and Watling, 1976; Zaroogian, 1980). Fluctuations in metal concentrations in Mytilus edulis have been attributed to variations in wet weight by Phillips (1976). It appeared that mussels with high wet weights had low concentrations of trace metals. It was suggested that total metal content remained almost constant throughout the year but that the mussels' weight change caused fluctuations in metal concentrations in the soft tissues. Although we observed higher chromium contents in larger than in smaller mussels, a significant relationship did not exist between concentration and dry weight.

Ayling (1974) stated that tissue concentrations of chromium in oysters is almost independent of the metal concentration at each site. In this study, oysters continued to accumulate chromium for up to $12 \mathrm{wk}$ with no indication that accumulation would not proceed with the continued addition of chromium to the seawater. We found that tissue chromium concentration is dependent upon seawater chromium concentration in both oysters and mussels. Shuster and Pringle (1968) also reported a similar relationship between seawater concentration and tissue concentration for chromium.

Shuster and Pringle (1969) used chromium concentrations (50 and $100 \mu \mathrm{g}^{-1}$ ) much higher than those employed in this study. Differences in uptake curves could be explained by the fact that Shuster and Pringle (1969) used trivalent chromium which is essentially insoluble in seawater and would be present as a particulate. Hexavalent chromium, which is soluble in seawater, was used in this study.

The logarithmic plots of the mussel data were not as clearly defined as the oyster plots. Uptake of chromium 
by mussels during this study was not continuous, particularly during the last $4 \mathrm{wk}$ of uptake. This could account for the poor fit of the logarithmic plots. Linear regression analyses of Shuster and Pringle's (1969) data indicated that chromium accumulation by Crassostrea virginica is a significant $(\mathrm{P}<0.01)$ linear function of time. In addition, the rate of chromium uptake in their oysters treated with $50 \mu \mathrm{g}^{-1}$ was extremely close to the rate obtained in this study when oysters were treated with $5 \mathrm{ppb} \mathrm{Cr}$ (slope coeff. 0.29 and 0.28 , respectively).

Less variability was observed with tissue chromium concentration among oysters than among mussels in samples collected during the accumulation period. The spawning process could contribute to the variability, since losses both in chromium content $(\mu \mathrm{g})$ and concentration $\left(\mu \mathrm{g} \mathrm{g}^{-1}\right)$ were observed in mussels and not oysters. Losses in chromium concentration were also expecied in oysters dunng spawning since it has been reported that metal uptake is interrupted in oysters during spawning (Cunningham and Tripp, 1973; Zaroogian et al., 1979; Zaroogian, 1980).

A greater loss in weight than in chromium content could be responsible for the continuous increase in chromium concentration observed during spawning. Weight losses $(16 \%)$ in the $5 \mathrm{ppb} \mathrm{Cr}$ treated oysters were greater than the losses in content $(13 \%)$ which would account for the increase in concentration during spawning. During this same period, the percentage increase in content $(21 \%)$ in the $10 \mathrm{ppb} \mathrm{Cr}$ treated oysters was more than twice the increase in weight $(10 \%)$ which could also account for an increase in concentration.

The continual increase in chromium content observed only in oysters treated with $10 \mathrm{ppb} \mathrm{Cr}$ during the spawning period could be due to the greater diffusion and accumulation of chromium interstitially at higher seawater chromium concentrations, thus resulting in increased chromium body burdens. If we assume that this unbound or loosely bound chromium would be lost from the tissues more rapidly than bound chromium upon termination of chromium addition, then the more rapid loss of chromium from oysters treated wih $10 \mathrm{ppb} \mathrm{Cr}$ than with $5 \mathrm{ppb} \mathrm{Cr}$ observed during the first 2 wk of depuration could be explained. As much as $32 \%$ chromium accumulated by oysters treated with $10 \mathrm{ppb} \mathrm{Cr}$ was lost after 2 wk depuration whereas no chromium loss from oysters was apparent during this period in those treated with $5 \mathrm{ppb} \mathrm{Cr}$. Similarly, $29 \%$ of the chromium in mussels treated with $10 \mathrm{ppb} \mathrm{Cr}$ was lost after $2 \mathrm{wk}$ depuration compared to a $0.1 \%$ loss in $5 \mathrm{ppb} \mathrm{Cr}$ treated mussels.

Pringle et al. (1968) suggested that the initial tissue concentration of a given metal appears to be directly related to the depletion rate for a given species.
Schulz-Baldes (1974) reported that the rate of lead loss from Mytilus edulis is closely correlated with the internal lead concentration. In the case of mercury loss from Crassostrea virginica, Cunningham and Tripp (1975) established that in a declining temperature regime greater losses occurred in oysters that received higher concentrations of mercury. Under conditions of a natural temperature decline, more than $54 \%$ of the lead concentration in C. virginica was lost after $4 \mathrm{wk}$ and loss did not appear to be constant (Zaroogian et al., 1979). Our findings indicated that the rate of chromium loss as concentration in oysters and mussels is not related to tissue concentration and loss appeared to occur at a constant rate.

In addition, it appears that chromium depuration is not entirely time and temperature dependent. Rather, chromium loss occurs slowly in oysters and mussels until a residual concentration of chromium in the tissue is attained, after which no chromium loss appears to occur.

The biological half-life of a metal is defined as the time required for half the concentration of accumulated trace metal to be lost (Renfro, 1973). Using the equation of Renfro (1973) for calculating biological half-life, times of 2 and $1 \mathrm{wk}$ were obtained for oysters and mussels, respectively. However, during $28 \mathrm{wk}$ depuration, a $50 \%$ loss in tissue chromium concentration was not observed in either species.

Butler et al. (1971) and Phillips (1976) recommended certain requisites for a biological indicator of metals. We feel that both Crassostrea virginica and Mytilus edulis satisfy the requirements for chromium. However, mussels appear to be better accumulators of chromium with their higher tissue concentrations in both treatments. Although the oysters accumulate less chromium than mussels, the individual variability is much less than in mussels. In addition, it appears that spawning does not affect uptake in oysters as it does in mussels. On these bases, it would appear that C. virginica would be a better indicator of chromium in its environment.

\section{LITERATURE CITED}

Ayling, G. M. (1974). Uptake of cadmium, copper, lead and chromium in the Pacific oyster Crassostrea gigas grown in the Tamar River, Tasmania. Wat. Res. 8: 729-739

Baptist, J. P., Lewis, C. W. (1969). Transfer of ${ }^{65} \mathrm{Zn}$ and ${ }^{51} \mathrm{Cr}$ Through an Estuarine Food Chain. In: Nelson, D. J., Evans, F. C. (eds.) Symposium on radioecology. University of Michigan, Ann Arbor, p. 420-430

Bond, R. G., Straub, C. P., Prober, R. (1973). Handbook of environmental control, Vol. III, Water supply and treatment. CRC Press, Cleveland, Ohio, p. 763-764

Butler, P. A., Andreim, A. L., Bonde, G. J., Jemelov A., Reisch, D. J. (1971). Monitoring organisms. F. A. O. Fish. Rep. 99 (Suppl. 1): 101-112 
Cunningham, P. A., Tripp, M. R. (1973). Accumulation and depuration of mercury in the American oyster Crassostrea virginica. Mar. Biol. 20: 14-19

Cunningham, P. A., Tripp, M. R. (1975). Factors affecting accumulation and removal of mercury from tissues of the American oyster Crassostrea virginica. Mar. Biol. 31: 311-319

Fukai, R. (1967). Valency state of chromium in seawater. Nature, Lond. 213: 901

MacKay, N. J., Williams, R. J., Kacprzac, J. L., Kazacos, M. W., Collins, A. J., Auty, E. N. (1975). Heavy metals in cultivated oysters (Crassostrea commercialis = Saccostrea cucullata) from estuaries of New South Wales. Aust. J. mar. Freshwat. Res. 26: 31-46

Mathis, B. J., Cummings, T. F. (1973). Selected metals in sediments, water and biota in the Illinois River. J. Wat. Pollut. Control Fed. 45: 1573-1583

Mertz, W., Angino, E. E., Cannon, H. L., Hambridge, K. M. Voors, A. W. (1974). Chromium. In: Geochemistry and the environment, Vol. I, The relation of selected trace elements to health and disease. National Academy of Sciences, Washington, D. C., p. 29-35

Phillips, D. J. H. (1976). The common mussel Mytilus edulis as an indicator of pollution by zinc, cadmium, lead and copper. 1. Effects of environmental variables on uptake of metals. Mar. Biol. 38: 39-69

Pringle, B. H., Hissong, D. E., Katz, E. L., Mulawka, S. T.
(1968). Trace metal accumulation by estuarine molluscs. J. sanit. Engng Div. Am. Soc. civ. Engrs 94: 455-575

Renfro, W. C. (1973). Transfer of ${ }^{65} \mathrm{Zn}$ from sediments by marine polychaete worms. Mar. Biol. 21: 3-5-316

Schulz-Baldes, M. (1974). Lead uptake from seawater and food, and lead loss in the common mussel Mytilus edulis. Mar. Biol. 25: 177-193

Snedecor, G. W., Cochran, W. G. (1967). Statistical methods. Ames, Iowa, lowa State University Press

Shuster, C. M., Pringle, B. H. (1968). Effects of trace metals on estuarine mollusks. Proc. 1st Mid-Atlantic Ind. Waste Conf., University of Delaware (CE-5), p. 285-304

Shuster, C. M., Pringle, B. H. (1969). Trace metal accumulation by the American eastern oyster, Crassostrea virginica Proc. natn. Shellfish. Ass, 59: 91-103

Towill, L. E., Shriner, C. R., Drury, J. S., Hammons, A. S. Holleman, J. W. (1978). Reviews of the environmental effects of pollutants: III. Chromium EPA-600/1-78-023, U.S. Environmental Protection Agency, Cincinnati, Ohio, p. 288

Watling, H. R., Watling, R. J. (1976). Trace metals in oysters from the Knysna estuary. Mar. Pollut. Bull. 7: 45-58

Zaroogian, G. E. (1980). Crassostrea virginica as an indicator of cadmium pollution. Mar. Biol. 58: 275-284

Zaroogian, G. E., Morrison, G., Heltshe, J. F. (1979). Crassostrea virginica as an indicator of lead pollution. Мат. Biol. 52: 189-196 